\title{
Perkembangan Bahasa Anak Usia 3 Tahun
}

\author{
Shofia Maghfiroh ${ }^{1}$, Delfi Eliza ${ }^{1}$ \\ Pendidikan Anak Usia Dini Fakultas IImu Pendidikan, Universitas Negeri Padang
}

$\triangle$ Corresponding author

(shofiamaghfiroh.sm@gmail.com)

\begin{abstract}
Abstrak
Penelitian ini bertujuan untuk mendeskripsikan perkembangan bahasa anak pada usia 3 tahun. Teknik pengumpulan data yang digunakan terdiri dari observasi dan dokumentasi selama empat hari. Hasil mini riset ini menunjukkan bahwa anak tersebut mengalami perkembangan bahasa sesuai dengan tingkat pencapaian pada usianya. Yang mana anak sudah mampu menggunakan 2 sampai 3 kata dalam pengucapan, kosakata yang dimiliki sudah lebih dari 50 kata.
\end{abstract}

Kata Kunci: Perkembangan bahasa; anak usia 3 tahun

\begin{abstract}
This study aims to describe the language development of children at the age of 3 years. The data collection technique used consisted of observation and documentation for four days. The results of this mini research show that the child experiences language development according to the level of achievement at his age. Where children are able to use 2 to 3 words in pronunciation, their vocabulary is more than 50 words.
\end{abstract}

Keywords: Language development; 3 year old child

\section{PENDAHULUAN}

Sesuai dengan Undang-undang Republik Indonesia Nomor 20 tahun 2003 tentang Sistem Pendidikan Nasional pada Pasal 1 ayat 14, menyatakan bahwa pendidikan anak usia dini adalah suatu upaya pembinaan yang ditujukan kepada anak sejak lahir sampai dengan usia enam tahun yang dilakukan melalui pemberian rangsangan pendidikan untuk membantu pertumbuhan dan perkembangan jasmani dan rohani agar anak memiliki kesiapan dalam memasuki pendidikan lebih lanjut (Depdiknas, 2003).

Hal ini menjelaskan bahwa pendidikan sangat penting distimulasi sejak usia kelahiran sampai 6 tahun. Dalam pemenuhannya, seorang anak akan mendapatkan pendidikan pertamanya di lingkungan keluarga. Keluargalah yang menjadi pendidik pertama untuk seorang anak. Oleh sebab itu keluarga dan pola asuhnya menjadi hal yang sangat berkaitan dengan tumbuh kembang seorang anak tersebut diantaranya adalah aspek perkembagan bahasa.

Sandra Bochner \& Jane Jones, dalam buku Child Language Development Learning to Talk : 2005 mengungkapkan bahwa bahasa merupakan salah satu bentuk komunikasi. Bahasa adalah sistem tanda atau simbol yang digunakan oleh sekelompok orang untuk berbagi makna. Tanda atau simbol tersebut berupa bunyi bahasa (tuturan) atau simbol tertulis (teks). Dalam proses pemerolehan bahasa anak, terdapat dua faktor utama yang berpengaruh. Faktor pertama adalah kemampuan bawaan anak atau disebut dengan bakat bahasa, sedangkan faktor kedua yaitu aspek lingkungan sekitar anak, terutama aspek lingkungan sosial yang memungkinkan bahasa dapat diterima oleh anak.

Bahasa merupakan hal yang penting dalam komunikasi dan kedua faktor tersebut sangat berpengaruh dalam perkembangan bahasa anak. Maka itu kita sebagai orangtua memberikan 
stimulasi yang baik untuk menunjang perkembangan bahasa anak. Karena bahasa pertama anak bermula dari lbunya atau dari rumah.

Bromley dalam Dhieni (1992) dalam menyebutkan bahwa terdapat empat aspek bahasa, yaitu menyimak, berbicara membaca dan menulis. Bahasa ada yang bersifat reseptif (menyatakan) dan ekspresif (dinyatakan). Contoh bahasa reseptif adalah mendengarkan dan membaca suatu informasi. Sedangkan contoh bahasa ekspresif adalah berbicara dan menuliskan informasi untuk dikomunikasikan kepada orang lain.

Pada buku Perkembangan Anak Usia Dini yang di tulis oleh Ahmad Susanto, 2011. Menjelaskan secara umum tahap-tahap perkembangan bahasa pada anak dapat dibagi ke dalam beberapa rentang usia, masing-masing rentang tersebut menunjukan ciri tersendiri. Tahap perkembangan ini sebagai berikut: 1) Tahap I (pralinguistik), yaitu antara 0-1 tahun. Tahap ini terdiri dari; Tahap meraban-1 (pralinguistik pertama). Tahap ini dimulai dari bulan pertama hingga bulan keenam dimana anak akan mulai menangis, tertawa, dan menjerit, Tahap meraban -2 (pralinguistik kedua). Tahap ini pada dasarnya merupakan tahap kata tanpa makna mulai dari bulan ke-6 hingga 1 tahun, 2) Tahap II (linguistik) tediri dari dua tahap, yaitu; Holafrastik (1 tahun), ketika anak-anak mulai menyatakan makna keseluruhan frasa atau kalimat dalam satu kata. Tahap ini juga ditandai dengan perbendaharaan kata anak hingga kurang lebih 50 kosa kata, Frasa (1-2 tahun), pada tahap ini anak sudah mampu mengucapkan dua kata (ucapan dua kata). Tahap ini juga ditandai dengan perbendaharaan kata anak sampai dengan rentang 50-100 kosa kata. 3) Tahap III (pengembangan tata bahasa, yaitu prasekolah 3,4,5 tahun). pada tahap ini anak sudah dapat membuat kalimat, seperti telegram. Dilihat dari aspek pengembangan tata bahasa seperti S-P-O, anak dapat memperpanjang kata menjadi satu kalimat. 4) Tahap IV (tata bahasa menjelang dewasa, yaitu 6-8 tahun). Tahap ini ditandai dengan kemampuan menggabungkan kalimat sederhana dan kalimat kompleks.

Jalongo (1992:8-9) mengelompokkan perkembangan linguistik ini sebagai tahapan kedua dan seterusnya, sebagaimana pada tabel 1.

Tabel 1. Perkembangan Linguistik

\begin{tabular}{|l|l|}
\hline \multicolumn{1}{|c|}{ Tahap Ketiga Membuat Kata-Kata Dalam Frase } \\
\hline Sekitar 2 tahun & $\begin{array}{l}\text { - Langkah yang baik dalam penerimaan bahasa; anak menggunakan } \\
\text { bahasa telegraphic yang terdiri dari } 2 \text { sampai } 3 \text { kata. } \\
\text { - Kosakata yang digunakan terdiri dari: } 350 \text { kata. } \\
\text { - Sosial: peningkatan pasti dalam upaya berkomunikasi dan anak mulai } \\
\text { menggunakan percakapan. } \\
\text { - Kadang mempertimbangkan periode paling cepat dalam perkembangan } \\
\text { bahasa. • Kosakata: banyak kata bertambah setiap hari; yakni 200-300 } \\
\text { kata. } \\
\text { - Sosial: anak berusaha untuk berkomunikasi dan menunjukkan frustasi jika } \\
\text { tidak memahami kemampuan orang lain (dewasa) untuk memahami, anak } \\
\text { meningkat dramatis. }\end{array}$ \\
\hline
\end{tabular}

Dari hasil observasi yang dilakukan oleh peneliti pada anak usia 3 tahun, terlihat pada table tersebut bahwa anak sudah dalam pencapaian perkembangan bahasanya sesuai usianya.

Menurut Tarmansyah (1996:50-61) ada beberapa faktor yang mempengaruhi perkembangan bahasa dan bicara pada anak. Faktor tersebut adalah: (1) kondisi jasmani dan kemampuan motorik, (2) kesehatan umum, (3) kecerdasan, (4) sikap lingkungan, (5) faktor sosial ekonomi, (6) jenis kelamin, (7) kedwibahasaan, dan (8) neurologi. Hal ini menjelaskan bahwa terdapat beberapa faktor yang dapat mempengaruhi perkembangan bahasa dan berbicara anak tersebut berkembang dengan baik atau mengalami keterlambatan. 


\section{METODE PENELITIAN}

Penelitian ini bersifat deskriptif dengan pendekatan kualitatif karena bertujuan untuk menggambarkan fenomena yang terjadi di lapangan. Subjek penelitian adalah 1 orang anak perempuan yang berusia 3 tahun 6 bulan. Teknik pengumpulan data yang digunakan terdiri dari observasi dan dokumentasi.

\section{HASIL DAN PEMBAHASAN}

Dari gambaran yang ditemukan di lapangan mengenai perkembangna bahasa anak usia 3 tahun 6 bulan dengan teknik pengumpulan data melalui observasi dan dokumentasi didapatkan hasi sebagai berikut :

\section{Mampu mengucapkan dua kata}

Anak sudah mampu mengucapkan dua kata seperti "buat jalan-jalan", "namanya bantal", dan beberapa dua kata lainnya yang sudah diuraikan pada laporan hasil observasi.

\section{Sudah mengusai lebih dari 50 kata}

Sudah banyak kata-kata yang dapat diucapkan anak dengan baik, meskipun ada beberapa huruf yang masih cadel tapi anak mampu menyampaikan dengan benar kata yang ia maksud.

\section{Banyak kata bertambah setiap hari}

Dari lembaran hasil observasi terlihat anak mampu mengusai kata dalam bahasa inggris.

\section{Anak berusaha untuk berkomunikasi dan menunjukkan frustasi jika tidak memahami kemampuan orang lain}

Pada hasil dokumentasi yang dilakukan peneliti terdengar dengan baik bahwa anak merespon komunikasinya jika ada yang tidak memahami.

Uraian ini dijelaskan menurut pengelompokkan perkembangan bahasa yang dipaparkan oleh Jalongo (1992:8-9), pada usia 2-3 tahun anak termasuk pada tahapan kedua dan seterusnya. Pada usia 3 tahun 6 bulan anak masuk dalam pengelompokkan bahasa tahap tiga yang mana anak mampu membuat kata-kata dalam frase.

\section{SIMPULAN}

Bahasa tidak dapat dipisahkan dengan bicara dan pikiran. Karena tanpa kita sadari bahwa saat berbicara dibutuhkan pengetahuan bahasa dan pikiran, tanpa dua hal tersebut ucapan bicara yang keluar tentu tidak terarah dan tidak dapat dipahami oleh pendengarnya. Pada anak usia 3 tahun 6 bulan masuk pada pengelompokkan tahap 2 ke atas, yang mana anak sudah mampu menguasai lebih dari 50 kata, anak sudah mampu mengucapkan dua kata, anak mampu berkomunikasi dengan intonasi jika pendengar tidak memahami, dan pada usia ini anak mampu menguraiakan kata-kata dalam frase. Kesalahan dalam berbicara pada anak mempunyai latar belakang dan alasan yang tidak selalu sama untuk setiap anak dan bentuk kesalahannya pun berbeda. Hal tersebut dapat diakibatkan oleh beberapa faktor, baik faktor dari luar maupun dari dalam diri anak. Dari mana pun asalnya faktor tersebut, orangtua sebagai orang yang pertama berada di lingkungan anak, dekat dengan anak, paham tentang perkembangan sosial-emosional, fisik, emosi, dan kognitif anak ketika anak berada di rumah hendaklah mampu dan mau menjadi pengarah, pembimbing, penyejuk, dan model bagi anak, agar mereka mampu dan terampil berbicara dengan kemampuan bahasanya. Untuk itu, orangtua perlu memiliki pengetahuan tentang ilmu pendidikan, psikologi perkembangan anak, perkembangan bahasa anak, memiliki penguasaan tentang kurikulum AUD dan teknik pengembangannya.

\section{DAFTAR PUSTAKA}

Bochner, Sandra \& Jane Jones. 2005. Child Language Development Learning to Talk (Second Edition). London: Whurr Publishers Ltd. 
Jalongo, Mary Renck. 1992. Early Childhood Laguage Arts. Singapore: Allyn and Bacon Undang-Undang RI Nomor 20 Tahun 2003

Susanto, Ahmad. Perkembangan Anak Usia Dini ( Jakarta: Kencana Prenada Media Group) 2011 Departemen Pendidikan Nasional, Pedoman Bidang Pengembangan Berbahasa Di Taman Kanak- kanak, (Jakarta, 2007

Robbbins dan Judge. 2007. Perilaku Organisasi, Buku 1 dan 2. Jakarta : Salemba Empat. Jakarta : Indeks

Martini Jamaris, Perkembangan Anak Usia Dini, (Surabaya, Cipta karya Utama, 2011),

Depdiknas, Perkembangan dan Konsep Dasar Pengembangan Anak Usia Dini, (Jakarta : Universitas Terbuka)

Aries Rochmadi, 2011., Penerapan Strategi Pembelajaran Melalui Bercerita; http://rohmadiaris21.blogspot.com.

Sari, AE, Upaya Guru Dalam Menumbuhkan Minat Baca Pada Anak (Bandung: Tugas Akhir D2 PGTK UPI Bandung, 2010) 